\title{
Information Sources in Physiotberapy
}

\author{
S. F. ROSSOUW
}

\section{SUMMARY}

The need for research workers to be thoroughly familiar with the literature is briefly discussed against the background of the information explosion. Methods of staying abreast of the current literature, as well as information sources and services available to obtain in-depth retrospective literature searches in physiotherapy are described, with emphasis on the major indexing and retrieval sources available in South Africa.

\section{INTRODUCTION}

A prime requirement in the execution of research of whatever nature is to ensure that the effort is not a repeat of research already carried out by someone else. In these days of scarce resources that would be unforgivable. In addition, one needs to be thoroughly familiar with the present state of knowledge on the subject.

To obtain the most recent information sources of an informal nature can often be tapped, such as talking to an expert or members of the so-called invisible colleges that exist for all disciplines. In general however, a comprehensive overview can only be obtained by using the formal media consisting of journal and review articles, monographs, and indexing and abstracting sources.

\section{THE GROWTH OF THE LITERATURE}

Since the appearance of the first ten scientific journals during the period 1665 to 1750 , the number of journals has increased consistently, by a factor of almost ten every fifty years. Today's researcher therefore has to deal with an exponential increase in the literature, the so-called information explosion. ${ }^{1}$

By 1850 , when there were about 300 journals, known as the primary literature, the researcher could no longer keep up to date with everything being published on his subject. The abstracting and indexing journals made their appearance at this stage in an effort to control the primary literature. Today there are more than 300 of these secondary information sources, each one covering a broad area of science.

S. F. Rossouw, D.Phil. Institute for Medical Literature, Medical Research Council, P.O. Box 70, Tygerberg 7505.

\section{OPSOMMING}

Die noodsaaklikheid dat navorsingswerkers heeltemal bekend met die literatuur moet wees word kortliks bespreek teen die agtergrond van die inligtingsuitbarsting. Wyse word beskryf om op hoogte van die huidige literatuur te bly, asook inligtingsbronne en -dienste wat beskikbaar is vir indiepte terugwerkende literatuurdeursoeke in fisioterapie met die klem op die hoof indeks- en herkrygingsbronne wat in Suid-Afrika beskikbaar is.

The usefulness of literature has its own half-life that varies with the discipline. For research purposes the most recent information is naturally of primary importance. For this reason, and especially so in medicine, the journal literature is the major source of recent information.

The methods and guides available to retrieve published information have improved greatly over the past decade. If the researcher will take the trouble of acquainting himself with these methods and sources he will have to devote much less time to the search for literature. This article describes some of the methods and services that are available for this purpose.

\section{CURRENT LITERATURE}

To stay abreast of the current literature in one's own field, it is customary to regularly scan new journals covering the subject. SERLINE, the US National Library of Medicine's catalogue of biomedical serials identifies no fewer than 43 current journals devoted to physiotherapy. (See Appendix 1.)

Obviously not all of these journals are of the same standing and some of them, especially those of professional associations in out-of-the-way parts of the world, can be ignored. This will however still leave one with a considerable number that may well be compulsory reading.

To make matters worse, there are a large number of excellent articles of relevance to physiotherapists being published in general medical periodicals such as the South African Medical Journal, or in journals largely devoted to other disciplines, e.g. Journal of Mental Deficiency Research or Journal of Pediatrics.

By rigorously selecting, within the limits both of available funds and time in which to read, a few core 
journals within the field can be subscribed to or found on the library shelves. ${ }^{2}$ This then still leaves the problem of making sure that one does not miss pertinent articles appearing in other journals.

\section{AIDS TO CURRENT AWARENESS}

Most medical libraries subscribe to Current Contents, an easy-to-scan, pocket-sized publication which displays tables of contents from thousands of the world's leading journals. Published weekly, the two editions of interest in keeping current with literature in physiotherapy are Life Sciences and Clinical Practice respectively.

Although Current Contents will bring articles from those journals not personally seen to one's notice, complete with the author's address for requesting reprints, quite often titles of articles are not a good enough clue as to their contents.

This problem can be overcome by taking out a subscription to a computerised current awareness service which will selectively bring references to relevant articles selected from thousands of journals to one's notice, usually including an abstract or summary of the article. This service is known as Selective Dissemination of Information (SDI) and can be obtained through most libraries as well as through the Medical Research Council's Institute for Medical Literature.

\section{RETROSPECTIVE LITERATURE SEARCHES}

The biggest problem facing the researcher at the start of a project is whether, in spite of his efforts to remain familiar with current knowledge, he has come across all the published literature on that particular topic.

Reviewing the literature is the only way to find out what the state of existing knowledge is, to gain the most informed approach to the topic, and to avoid reduplication of effort. ${ }^{3}$ In view of the vast ${ }^{3}$ literature in medicine and the para-medical sciences, this presents a real problem.

The traditional way of searching the literature is of course to consult abstracting and indexing sources, the secondary literature referred to above. All of these sources are available in printed form in most libraries and include the well-known Index Medicus.

Depending on the exhaustiveness of the search and the period to be covered, considerable time can be expended in carrying out a comprehensive search of the literature by means of printed indexes.

The main reason for this is that one can look under only one heading or keyword at a time and must repeat this process through all of the years to be covered.

Due to the computerization of typesetting during the last two decades, ${ }^{4}$ all of these printed indexes now also exist as computerised databases which can accurately be searched at great speed. Quite complex searches can be carried out in which all the facets of a search are linked in one run, retrieving highly relevant citations.

By getting to know more about these databases, the subject coverage of each, which journals and other material are included, and the way the material is indexed and presented, the researcher will be able to find relevant information faster and more effectively.

When using a particular printed source for the first time, it is advisable to obtain guidance from the library staff, as they are well acquainted with these tools. Computer searches of the databases can be obtained though information centres such as the Medical Research Council's Institute for Medical Literature.

\section{BIOMEDICAL DATABASES COVERING PHYSIOTHERAPY}

There is as yet no single source covering all the literature in the field of physiotherapy, the closest being Excerpta Medica's Section 19: Rehabilitation and Physical Medicine. For a comprehensive search it is therefore necessary to consult more than one of the secondary sources. Even such unlikely sources as engineering indexes may contain surprisingly relevant citations in the field of physiotherapy.

Although this article stresses computerised databases, it should be remembered that they generally provide coverage of the literature only for the last 15 to 20 years. The printed counterparts go much further back and should be used if necessary.

\section{Index Medicus/MEDLINE}

The oldest and probably most used index to the medical literature, including physical therapy, is a monthly publication of the US National Library of Medicine called Index Medicus. Under a succession of titles it has appeared since 1879 and today indexes some 2500 biomedical journals from all over the world, ${ }^{5}$ including 28 devoted to physical therapy, rehabilitation and sports medicine.

Before commencing a search of Index Medicus it is advisable to consult the thesaurus used in indexing the articles. This word list, known as Medical Subject Headings (MeSH), is published annually with the January issue. The alphabetical part of MeSH provides cross references between terms, and leads one to more general or more specific terms or to related terms.

The headings of all medical subjects currently in use are arranged in a hierarchial manner showing relationships between broader and narrower terms in that section of the $\mathrm{MeSH}$ publication known as the Tree Structures. It is strongly recommended that the Trees be consulted to identify all relevant terms to cover the topic before commencing a search of the alphabetically arranged Index Medicus.

The contents of all issues of Index Medicus from 1966 up to the present are computer-searchable in an online database known as MEDLINE. This enables one to link keywords (or rather Mesh Headings) denoting various aspects of a topic, thus overcoming the limitations of single word searching in the printed index.

A search through Index Medicus for literature on the management of phantom limb pain by means of electrotherapy, for instance, would take a fair amount of time - all of the current year's monthly issues, and sometimes those of the previous year's as well, would have 
to be individually scanned, followed by searching of the annual cumulations of earlier years. To search back to 1966 at an average of 3 minutes per annual volume would take at least 60 minutes merely locating the central concept (phantom limb) and scanning titles for the other aspects, i.e. pain and electrotherapy.

Doing the same search on the consolidated MEDLINE file (1966-1985) with a combination of all three relevant $\mathrm{MeSH}$ headings (Electrotherapy and Phantom Limb and Pain) took exactly 39 seconds to establish that 14 articles were published in this period. One has the further advantage that the computer produces a nicely printed bibliography, including abstracts for about half the citations.

Much more complicated searches can as easily be performed with MEDLINE. Other advantages include the capability to limit retrieval to articles from particular time periods, to articles in specific languages, or dealing with experimental or clinical research or practice, or limited by age group or sex. Very new concepts not yet represented in $\mathrm{MeSH}$, or even buzz words or jargon words, can be retrieved from the database if used in titles or abstracts of articles.

\section{Excerpta Medica/EMBASE}

The Excerpta Medica database (EMBASE) contains biomedical and pharmaceutical information taken from more than 3500 primary journals published in many different countries and languages. The database is divided into 46 numbered sections, corresponding to broad subject areas which often coincide with a traditional medical specialty, and a printed publication is produced for each section. ${ }^{6}$

Section 19 is entitled Rehabilitation and Physical Medicine and can be subscribed to separately. The subdivision of this abstract journal reflects the multiplicity of aspects of physical medicine and the care of the disabled which it covers. Some 15 journals devoted to physiotherapy are indexed for this section.

In spite of the convenience of having most of the directly pertinent literature grouped together, it may still be necessary to consult at least seven of the other printed sections to obtain information on topics such as anatomy, arthritis and rheumatic disease, bioengineering, cardiovascular rehabilitation, exerise physiology or orthopaedics.

All 46 sections from 1973 onwards are simultaneously searchable in the EMBASE computerised database however, again with the convenience of linking various aspects and the ability to limit retrieval to time periods, languages or the other parameters already mentioned.

The foregoing two databases will probably between them cover the literature of physiotherapy to a very large extent and can be regarded as a minimum for research purposes. However, for very specialised approaches such as psychological, pharmaceutical, chemical, educational, biological or bioengineering aspects of databases physiotherapy, a spectrum of other databases may have to be consulted. ${ }^{7,8}$

Some of these databases will be mentioned very briefly, with a sample citation from each to illustrate the type of information that can be obtained from them. Although abstracts are available in the databases, they are omitted from the samples.

\section{Psychological Abstracts/PSYCINFO}

This database covers the world's literature on psychology and allied fields, including treatment and prevention of physical and psychological disorders. Physical disorders include cardiovascular, congenital, musculoskeletal and respiratory tract disorders. The treatment category also covers the use of treatment techniques other than psychotherapy, including speech therapy, surgical techniques and medical treatment methods, and occupational physiotherapy.

Produced by the American Psychological Association, Psychological Abstracts contains citations with abstracts from journals, reports, serial publications and other sources. The computerised database, PSYCINFO, has additional material from Dissertation Abstracts. Retrospective searches of the literature going back to 1967 are possible. ${ }^{9}$

Sample citation

\section{2-18357}

Behavioral physical therapy and spina bifida: A case study.

Rapport, Mark D.; Bailey, Jon S.

U Rhode Island, Kingston.

Journal of Pediatric Psychology, 1985 Mar Vol 10(1) 87-96.

\section{Biological Abstracts/BIOSIS}

Just as the psychological factors playing a part in treatment are of interest to the physiotherapist, so too are the basic biological processes and principles underlying health and disease. When information dealing with this aspect is required, an excellent database to turn to is BIOSIS.

The computerised BIOSIS contains citations from the printed Biological Abstracts and from BA/Reports, Reviews, Memoranda. Together, they constitute the major English language service providing comprehensive world, wide coverage of research in the life sciences.

The database subject coverage includes studies on the physiological activities and functions of animal and human organs, and limbs and body parts. E.g. endurance, locomotion and metabolic changes during exercise; physiological, physical and emotional stress, tension or shock; and studies on physical exercise, recreation, sports, posture and physiotherapy. ${ }^{10}$

Sample citation:

\section{2}

Electromyographic biofeedback and physical therapy of the hemiplegic upper limb.

Inglis $\mathbf{J}$; Donald MW; Monga TN; Sproule M; Young MJ.

Dep. Psychol., Queen's Univ., Kingston, Ontario, K7L 3N6, Can.

Arch Phys Med Rehabil, 65(12), 1984: 755-759. 


\section{Chemical Abstracts/CHEMABS}

The chemical reactions of normal and pathological states, and the regeneration of mammalian cells, tissues, or organs, both in the normal biochemistry of these entities and in their recovery from trauma or a pathological state are often of importance in physiotherapy.

The printed Chemical Abstracts was started in 1907, with a computerised database available for retrospective searching from 1967 to the present day. It contains English-language abstracts and indexes to the world's literature of chemistry."

The following is a sample citation from CHEMABS: 67041916 CA: 67(9)41916e Conference Proceeding Effect of physical therapy in gastrointestinal tract diseases on some serum protein indexes.

Finogenov, V. S.

Tr. Nauchn. Konf. Kirg. Nauchno-lssled. Inst. Kurortol.

Fizioter., 3rd, 1963: 385-90.

\section{International Pharmaceutical Index/IPA}

The influence of medicinal drugs on a patient undergoing physiotherapy is frequently of interest to the therapist who may require full information for patient care or research purposes.

The IPA database and its printed equivalent are products of the American Society of Hospital Pharmacists. Consisting of refecences to journal articles, the database covers more than 600 worldwide publications from 1970 to the present. This file, therefore, is the most comprehensive of the pharmaceutical literature abstracting services. ${ }^{12}$

Sample citation:

\section{$959022-05514$}

State of the pain therapy today.

Krainick, J. U.; Waisbrod, H.; Herlinnger, C.

Schmerzzentrum Mainz, Neurochirurgiasche Abtlg., Auf d. Steig 14-16 6500 Mainz, FRG.

Pharm. Ztg. 129: 1894-1897 (Aug. 16) 1984.

\section{Science Abstracts/INSPEC}

The Science Abstracts family of abstract journals, indexes, and title bulletins commenced publication in 1898. Today it is the largest English-language database in the field of physics, electrotechnology, computers and control, and information technology. Retrospective searches can be done in the computerized version from 1976 onwards.

Topics in biophysics, medical physics and biomedical engineering are extensively covered, e.g. biophysics of neurophysiological processes, biomechanics, technobiology of patient care and treatment such as prosthetics, and other practical applications such as sonic and ultrasonic equipment. ${ }^{13}$

Sample citation:

1443271 A85050752, B85026757

Medical ultrasonics

Wells, P. N. T.

Bristol Gen. Hospital, England.

IEEE Spectrum (USA), Vol. 21, No. 12; 44-51 Dec. 1984.

\section{Educational Resources Information Center/ERIC}

ERIC is the complete database on educational materials, consisting of two main files: Resources in Education, which is concerned with identifying the most significant and timely education research reports and projects; and Current Index to Journals in Education, an index of more than 700 periodicals of interest to every segment of the educational profession. ${ }^{14}$

Topics such as education and training of physiotherapists, curriculum planning, facilities and staffing in physiotherapy training, or the application of physiotherapy in general education can all be searched for in ERIC

Typical citation:

\section{EJ230420 EC114699}

Physiotherapy in ordinary schools.

Davies, Jean; Hunt, Agnes.

Special Education: Forward Trends, v7 nl p29-31 Mar 1980.

\section{OBTAINING A COMPUTERISED SEARCH}

With the proliferation in home and personal computers, some of the database vendors have introduced software revisions that will enable researchers to do their own searching on databases..$^{15,16,17}$ Not all of these efforts have been completely successful. ${ }^{18}$

It is more customary, and mostly more efficient and cost-effective, to have the search done through a library or information service such as that provided by the Institute for Medical Literature (IML) of the South African Medical Research Council. IML has been involved in online searching of databases on behalf of the biomedical community since 1976. ${ }^{19}$

Advice on the choice of the most appropriate database(s) for a particular search, and requests for retrospective searches and/or current awareness subscriptions, can be submitted to IML by telephone or through the post. It is useful if a personal visit can be made to the Institute as the researcher can then be present when the online search is carried out and can make suggestions to improve relevancy of retrieved citations.

There is a modest one-time fee payable for each retrospective search to cover the cost of telecommunications, computer usage, and print charges. Current awareness subscriptions, which provide the subscriber with a monthly printout of recent references on his particular topic, are renewable annually.

\section{CONCLUSION}

The necessity for research workers to be familiar with the literature is so apparent that it need not be stressed. However, the daunting prospect of having to spend hours on searching the literature need no longer be faced as a wide variety of computerised databases and services are available for this purpose.

\section{References}

1. Doyle LB. Information retrieval and processing. Los Angeles: Melville, 1975: 3. 
2. Scheckler WE. A realistic journal reading plan: the cornerstone of continuing medical education. JAMA 1978; 248: 1987-1988.

3. Wilkins RH. Preparation of a neurosurgical manuscript, with emphasis on library research. Clin Neurosurg 1981; 28: 173-192.

4. Miles WD. A history of the National Library of Medicine. Washington, DC: U.S. G.P.O., 1982: 368.

5. Rogers FB. Index Medicus in the twentieth century. In: Blake JB, ed. Centenary of Index Medicus. Bethesda, MD; National Library of Medicine, 1980: 53-61.

6. Guide to the classification and indexing system. 2nd ed. Amsterdam: Excerpta Medica, 1984.

7. Tenopir $C$. Online information in the health sciences. Libr. J. 1983; 108: 1932-1933.

8. Powell JR. Excerpta Medica (EMBASE) online - a reacquaintance. Online 1980; 4: 36-41.

9. PSYCINFO user reference manual. Washington, DC: American Psychological Association, 1981.

I0. BIOSIS Search guide. Philadelphia: BioSciences Information Service, 1985.

11. Subject coverage and arrangement of abstracts by sections in Chemical Abstracts. Columbus: American Chemical Society, 1982.

12. Kruse $\mathrm{KW}$. Online searching of the pharmaceutical literature. Am J. Hosp. Pharm. 1983; 40: 240-253.

13. INSPEC user manual. Hitchin, Herts: Institution of Electrical Engineers, 1985.

14. All about ERIC. Washington, DC: U.S. G.P.O., 1982.

15. Ojala M. Knowledge Index: a review. Online 1983; 7: 3I-34.

16. Janke RV. BRS/After Dark: the birth of online selfservice. Online 1983; 7: 12-29.

17. Doszkocs TE. CITE NLM: natural-language searching in an online catalog. Information Technol Libr. 1983; 2: 364-80.

18. Griffith JC. Why can't 1 do it? Emerging training concerns of end users and online professionals. Online 83 Conf Proc. 1983; 77-80.

19. Rossouw SF. Hello from ElHill 3. S. Afr. Libr. 1976; 44; 109-112.

Appendix 1

\section{PHYSICAL THERAPY JOURNALS}

\section{A. English language}

1. Abuh Physio. Zaria, N1, Dec 1979

2. American Journal of Physical Medicine. Baltimore, V.31, 1952-

3. Australian Journal of Physiotherapy. Sydney, V.1, 1954-

4. Clinics in Physical Therapy. New York, V.1, 1981-

5. International Perspectives in Physical Therapy. Edinburgh, V.1, 1985-.

6. Journal of Orthopaedic and Sports Physical Therapy. Washington, V.1, 1979
7. Medical Ultrasound. New York, V.I, 1977 -

8. New Zealand Journal of Physiotherapy. Wellington, V.1, 1938 -

9. Physical and Occupational Therapy in Geriatrics. New York, V.1, 1980-

10. Physical and Occupational Therapy in Pediatrics. New York, V.1, 1980-

11. Physical Therapy. Washington, 'V.44, 1964-

12. Physiotherapy. London. V.34, 1948-

13. Physiotherapy Canada. Toronto. V.24, 1972-

14. Progress in Medical Ultrasound. Amsterdam. V.1, 1980-

15. Ultrasound Annual. New York. 1982-

\section{B. Non-English}

1. Acta Belgica. Medica Physica. Bruxelles, V.6, 1983-

2. Annales de Kinesitherapie. Paris, V.1, 1974-

3. Biuletin po Kurortologiia, Fizioterapiia i Lechebna Fizkultura. Sofia, 1959?-

4. Cahiers de Kinesitherapie. Clermont-Ferrand, N1, 1962?-

5. Chung-Hua li Liao Tsa Chih. Chinese Journal of Physical Therapy. Anshan.

6. Clinica Termale. ROME, V.2, 1948-

7. Danske Fysioterapeuter. Copenhagen, V.56, 1974-

8. Fizicheskie i Kurortyne Faktory i ikh Lechebnoe Primenenie. Kiev, V.8, 1974

9. Interdisziplinare Physiotherapie und Rehabilitation. Erlangen, Bd.1, 1982-

10. Journee de Reeducation. Paris, 1974?-197?

11. Krankengymnastik. Munich, V.1, 1949-

12. Kurortologiia i Fizioterapiia. Kiev, V. 10, 1977 -

13. Kurortologiia i Fizioterapiia. Sofia, V.1, 1964?-

14. Laakintavoimistelija. Fysioterapeuten. Helsinki, 1971?

15. Manualle Medizin. Heidelberg, 1963?--

16. Monographien zur Physikalischen Therapie und Farbtestpsychologie. Bonn, V.1, 1966-

17. Nauchni Trudove - Nuachen Institut po Kurortologiia, Fizioterapiia i Rekhabilitatsiia. Sofiia. V.13, 1976-

18. Nederlands Tijdschrift voor Fysiotherapie. Amsterdam, V. $76,1966-$

19. Paramedische Compendia; Serie A: Algemene Fisiotherapie. Lochem. V.1. 1968-

20. Physiotherapie. Lubeck, 1969?-

21. Rigaku Ryoho to Sagyo Ryoho. Japanese Journal of Physical Therapy and Occupational Therapy. Tokyo, V.I 1967-

22. Sbornik Nauchnykh Trudov; Nauchno-lssledovatelskii Institut Kurortologii i Fizioterapii. Erevan, V.8, 1964-

23. Sbornik Trudov-Azerbaidzhanskii Nauchno-Issledovatelskii Institut Kurortologii i Fizicheskikh Metodov Lecheniia im. S.M. Kirova. Baku, V.2, 1956-

24. Sporttherapeutische Praxis. Lubeck, V.1, 1977-

25. Voprosy Kurortologii i Fizioterapii. Frunze, 196?-

26. Voprosy Kurortologii i Fizioterapii. Tomsk, V.1, 1961-

27. Zeitschrift fur Orthopadie and ihre Grenzgebiete. Stuttgart, V.64, 1935

28. Zeitschrift fur Physiotherapie. Leipzig, V.23, $1971-$

\section{ERRATUM}

\section{PRIVATE PRACTITIONERS ASSOCIATION DIRECTORY}

Please note that the correct address of Mrs. A. Rohloff is 59 4th Beach, Clifton, Cape Town and not Old
Mutual Building, Darling Street, Cape Town as printed in the above directory. Telephone 021-489609. 